\title{
Manajemen Risiko Penyakit Unggas pada Peternak dan Pedagang Ayam Broiler di Jawa Barat
}

\author{
Risk Management of Poultry Disease in Broiler Breeders and Traders in West Java \\ Muhammad Ismail ${ }^{1 *}$, Eko Ruddy Cahyadi ${ }^{2 \sharp}$, dan Hartrisari Hardjomidjojo ${ }^{3 \sharp}$ \\ ${ }^{1}$ Mahasiswa Pascasarjana Program Studi Ilmu Manajemen IPB \\ ${ }^{2}$ Departemen Manajemen, Fakultas Ekonomi dan Manajemen IPB \\ ${ }^{3}$ Departemen Teknologi Industri Pertanian, Fakultas Teknologi Pertanian IPB \\ * Jl. Kamper Kampus IPB Dramaga, Bogor 16680
}

\begin{abstract}
ABSTRAK
Produk peternakan merupakan komoditas penting di Indonesia. Ayam broiler menjadi salah satu komoditas konsumsi utama di masayarakat. Tingginya permintaan terhadap ayam broiler perlu diiringi dengan pengawasan terhadap mutu produk. Pengawasan mutu produk salah satunya dengan manajemen risko penyakit unggas. Tujuan penelitian mengkaji perilaku peternak dan pedagang dalam memitigasi penyebaran penyakit unggas. Penelitian ini dilakuan dengan memetakan rantai pasok ayam broiler hidup untuk mengetahui saluran distribusi, menganalisis perilaku peternak dan pedagang untuk mengetahui mitigasi penyakit yang optimal, dan analisis regresi linear berganda untuk menganalisis faktor-faktor penyebab kematian. Lokasi penelitan dilakukan di empat daerah, yaitu Kabupaten Ciamis, Kabupaten Tasikmalaya, Kabupaten Subang, dan Kabupaten Sukabumi. Hasil dari penelitian menunjukkan rantai pasok ayam broiler berbeda untuk tiap-tiap daerah. Semakin panjang saluran distribusi, maka risiko penyebaran penyakit semakin tinggi. Peternak dan pedagang pada umumnya mengetahui penyakit unggas dan gejala-gejala ayam yang terjangkit penyakit. Pengetahuan peternak dan pedagang tentang gejala flu burung yang lebih baik terbukti dapat menurunkan risiko kematian ayam broiler selama penanganan. Lebih dari $64 \%$ peternak memilih memisahkan ayam sakit dengan ayam sehat, 22\% memilih mengobati ayam sakit, $11 \%$ menjual semua ayam sakit dan 3\% memusnahkan ayam sakit. Mayoritas pedagang memitigasi penyakit hanya dengan membersihkan kendaraan dan keranjang tanpa disinfektan. Tingkat kematian ayam pada pedagang meningkat nyata seiring dengan meningkatnya jumlah pembelian dan jarak pengangkutan.
\end{abstract}

Kata kunci: behavior of breeders and traders, manajemen risiko, multiple linear regression analysis, poultry disease, pemetaan rantai pasok

\section{ABSTRACT}

Livestock products are an important commodity in Indonesia. Broiler chickens are one of the main consumption commodities in the community. The high demand for broiler chickens needs to be accompanied by supervision of product quality. Product quality control is one of them is the management of poultry disease risk. The research objective is to determine the behavior of breeders and traders in mitigating the spread of poultry disease. This study was conducted by mapping the supply chain of live broiler chickens to find out the distribution channel, analyzing the behavior of breeders and traders to determine optimal disease mitigation, and multiple linear regression analysis to determine the causes of death. Research locations were conducted in four regions, namely Ciamis Regency, Tasikmalaya Regency, Subang Regency, and Sukabumi Regency. The results of the study show that the supply chain of broiler chickens is different for each region. The longer the distribution channel, the higher the risk of spreading the disease. breeders and traders generally know poultry diseases and the symptoms of chickens infected with the disease. Knowledge of breeders and traders about bird flu symptoms that are better proven to reduce the risk of death of broiler chickens during handling. More than $64 \%$ breeders chose to separate sick chickens form healthy chickens, $22 \%$ chose to treat sick chikens,

\footnotetext{
*) Korespondensi:

Departemen Manajemen FEM IPB, Jl. Kamper Kampus IPB Dramaga Bogor 16680; email: ismail.fahutan46@gmail.com
} 
$11 \%$ sold all si hicens, and 3\% destroyed sick chikens. The majority of traders mitigate the disease only by cleaning vehicles and baskets without disinfectants. The mortality rate of chickens in traders significantly increased along with the increase in the number of purchases and the distance of transportation.

Key words: behavior of breeders and traders, multiple linear regression analysis, risk management, poultry disease, value chain mapping,

\section{PENDAHULUAN}

Sektor peternakan merupakan bagian dari sektor pertanian yang memiliki peran dalam pemenuhan kebutuhan pangan di Indonesia. Pertumbuhan sektor peternakan selama periode 2004-2014 tidak meningkat nyata dari $12.4 \%$ menjadi $12.7 \%$, namun dari tren pertumbuhannya meningkat dari $3 \%$ menjadi $5 \%$, yang mengindikasikan adanya kemajuan kinerja pada sektor peternakan di Indonesia (BPS, 2015). Salah satu komoditas peternakan adalah ayam broiler atau daging ayam ras. Ayam broiler merupakan bagian dari komoditas peternakan yang menjadi salah satu sumber protein hewani penting. Ketersediaan yang melimpah menjadikan komoditas ini relatif terjangkau bagi masyarakat Indonesia. Produksi ayam broiler di Indonesia pada tahun 2014 sebesar $1.500,38$ ribu ton dari total produksi komoditas daging 2.925,21 ribu ton (Ditjennak, 2016). Menurut Subdirektorat Statistik Perdagangan Dalam negeri (2015), Jawa Barat merupakan sentra produksi ayam broiler terbesar di Pulau Jawa dan di Indonesia.

Salah satu permasalahan dalam industri unggas adalah penyebaran penyakit yang berpotensi menular melalui rantai pasok (Cardona et al. 2009). Banyaknya permasalahan menjadi hambatan dalam penanggulangan penyakit, sehingga sulit mencapai hasil diinginkan. Isolasi peternakan/daerah bebas penyakit masih sulit dilakukan, maka tingkat keberhasilan vaksinasi saat ini sangat bervariasi. Biosekuriti cenderung diperlonggar, karena memerlukan biaya tinggi. Kontrol lalu lintas unggas, produk asal unggas, produk sampingan (khususnya kotoran) sulit dilakukan. Kesadaran peternak untuk ikut mencegah perluasan penyebaran penyakit cenderung menurun. Menurut Mulyantini (2010), kematian ayam broiler dapat disebabkan oleh beberapa faktor, seperti penularan penyakit yang dapat berasal dari unggas satu ke unggas yang lain, atau dari induk keturunannya, seperti bakteri, virus, jamur, dan lainnya, serta penyakit yang tidak menular, seperti kekurangan gizi, suhu lingkungan ekstrim, perkandangan tidak baik, stress, dan lainnya. Di dalam praktek produksi unggas dan tataniaga banyak tahapan yang bisa menjadi faktor risiko penyebaran penyakit, sehingga perlu dilakukan identifikasi lebih lanjut untuk mengeliminasi risiko atau mengurangi risiko. Menurut Cardona et al. (2009), kematian ayam broiler dapat disebabkan salah satunya karena adanya risiko flu burung yang masuk dan menyebar nyata, melalui unggas, proses pengiriman, moda transportasi, dan kendaraan.

Salah satu cara mereduksi risiko atau mengurangi risiko penyebaran penyakit adalah melakukan identifikasi jaringan distribusi, manajemen dan pengendalian risiko rantai pasok terkait penyebaran penyakit pada rantai pasokan ayam broiler. Menurut Yupiana et al. (2010), orang-orang yang berhubungan dekat dengan ungggas (peternak, kurir/pedagang, pemotong, dll) harus mempertimbangkan risiko tinggi penyebaran penyakit yang kebanayakan dari mereka memiliki pengetahuan dan kesadaran yang buruk terhadap infeksi HPAI. Faktor yang perlu menjadi perhatian meliputi proses beternak, sistem, sumber daya manusia (SDM), dan kejadian di luar perusahaan. Pelaku yang perlu diperhatikan adalah perusahaan inti, peternak dan ritel yang berperan dalam rantai pasokan ayam broiler.

Melihat latar belakang yang telah dijelaskan, maka secara khusus tujuan penelitian ini adalah:

1. Mengidentifikasi karakteristik rantai pasok peternak dan pedagang di Jawa Barat.

2. Menganalisis perilaku peternak dan pedagang dalam pengendalian penyakit unggas

3. Menganalisis pengaruh rantai pasok pada kematian unggas di lingkup peternak dan pedagang

\section{METODE PENELITIAN}

Penelitian ini dilakukan selama bulan MeiOktober 2016 bertempat di Kabupaten Ciamis, Kabupaten Tasikmalaya, Kabupaten Subang dan Kabupaten Sukabumi. Jenis data yang digunakan pada penelitian ini adalah data primer dan sekunder. Pengumpulan data primer dilakukan dengan cara melakukan survei dan wawancara 
dengan kuesioner. Untuk data sekunder dilakukan studi pustaka dari berbagai sumber yang tersedia.

Pemilihan lokasi dilakukan secara bertahap (multistage sampling), dimana pemilihan kabupaten dilakukan secara sengaja (purposive) berdasarkan pertimbangan jumlah populasi unggas, jumlah populasi peternak dan jumlah frekuensi kejadian penyakit Avian Influenza. Pemilihan lokasi kecamatan dilakukan secara sengaja (purposive) berdasarkan pertimbangan variasi tingkat keparahan dan frekuensi terserang penyakit Avian Influenza. Penentuan responden dilakukan secara acak (random sampling) berdasarkan data pelaku rantai pasok yang ada di dinas peternakan dan kecamatan.

\section{Teknik Pengolahan dan Analisis Data}

Pengolahan dan analisis data pada penelitian ini menggunakan Analisis Deskriptif untuk mendiskripsikan obyek penelitian melalui data yang telah terkumpul. Value Chain Mapping digunakan untuk mengetahui saluran distribusi yang terjadi pada rantai pasok ayam broiler. Analisis persepsi dan perilaku peternak, serta pedagang untuk mengetahui perlakuan terhadap ayam broiler yang sakit. Analisis terakhir yang dilakukan adalah Analisis Regresi Linear Berganda untuk menjelaskan pengaruh rantai pasok pada kematian unggas di lingkup peternak dan pedagang. Data yang diperoleh diolah dengan menggunakan Software IBM Statistical Package for the Social Science (SPSS).

\section{HASIL DAN PEMBAHASAN}

Keadaan geografis dan demografis Jawa Barat sangat cocok untuk pengembangan budidaya peternakan, khususnya peternakan unggas. Jawa Barat merupakan daerah dengan ciri bentangan pegunungan dengan ketinggian 100-1500 meter di atas permukaan laut. Rata-rata suhu udara di Jawa barat antara $9^{\circ}-34^{\circ} \mathrm{C}$ dengan curah hujan per tahun berkisar 2000-5000 mm/tahun (BPS, 2015). Kondisi ini memacu pertumbuhan produksi unggas terus meningkat. Persebaran sentra produksi unggas yang diteliti dalam studi ini tersebar di beberapa kabupaten antara lain Ciamis, Tasikmalaya, Sukabumi dan Subang. Empat kabupaten tersebut termasuk kabupaten yang memiliki jumlah produksi unggas khususnya ayam pedaging terbesar di Jawa Barat (BPS, 2015).

\section{Karakteristik Responden}

Karakteristik peternak di Kab. Ciamis, Tasikmalaya, Sukabumi dan Subang dapat dilihat berdasarkan jenis kegiatan usahanya yang terdiri dari peternakan maklun, mandiri, kemitraan/ kontrak harga, dan perusahaan. Peternak maklun adalah peternak yang modal, biaya proses produksi dan pemasaran tidak sepenuhnya dilakukan sendiri oleh peternak, tetapi ada beberapa unsur yang dibantu pihak lain sesuai keinginan dan kemampuan peternak dalam perjanjian tertentu. Peternak mandiri adalah peternakan dengan kepemilikan modal dan seluruh biaya produksi sepenuhnya ditanggung oleh pemilik/peternak itu sendiri serta memasarkan hasil produksinya. Peternak kontrak harga adalah sistem kerjasama antara peternak dan perusahaan, dimana peternak hanya bertanggungjawab melaksanakan budidaya hingga ayam broiler siap panen dan mendapatkan keuntungan berdasarkan perjanjian atau kontrak harga yang telah disepakati. Peternakan perusahaan adalah sistem peternakan yang kepemilikan modal, biaya produksi dan pemasaran ditanggung oleh perusahaan, peternak hanya bertugas sebagai pekerja dan mendapat upah

Dalam bisnis perdagangan ayam broiler, terdapat dua jenis pedagang. Sebagian responden lebih sering berperan sebagai pedagang pengumpul dan lainnya sebagai broker. Pola bisnis untuk pedagang pengumpul adalah menyimpan ayam broiler yang telah dibeli dari peternak ke tempat penampungan yang sudah disediakan sebelum menjualnya ke pedagang lain. Pola bisnis broker melakukan sistem penjualan ayam broiler dengan surat delivery order (DO) atau menjual informasi terkait penjualan ayam broiler dan menawarkan ke pedagang lain, sehingga broker terakhir yang bertanggungjawab untuk mengambil ayam broiler dari peternak.

\section{Analisis Jaringan Distribusi Rantai pasok Ayam Broiler}

Pemetaan rantai nilai dapat menggambarkan kerangka yang sesuai dan efisien sehingga dapat dilakukan perencanaan dan pengujian suatu kebijakan dari HPAI untuk pencegahan dan berbagai pilihan pengendalian. Peta tersebut berfungsi sebagai alat komunikasi antara para ahli, stakeholders dengan berbagai latar belelakang dan kepentingan (McLeod et al. 2009). Karakteristik pada struktur jaringan distribusi rantai pasok ayam broiler pada umumnya sama. Karakteristik tersebut meliputi tiga pola aliran, 
yaitu aliran produk, aliran keuangan dan aliran informasi. Aliran produk mengalir dari hulu ke hilir, yaitu dari peternak ayam broiler sampai ke konsumen akhir. Aliran keuangan mengalir dari hilir ke hulu, yaitu dari konsumen akhir ke peternak ayam broiler. Aliran informasi mengalir secara timbal balik pada tiap mata rantai. Jaringan distribusi ayam broiler akan ditunjukkan oleh Value Chain Mapping yang digambarkan ke dalam empat kabupaten, yaitu Kabupaten Ciamis, Tasikmalaya, Subang dan Sukabumi.

Hubungan rantai pasok ayam broiler di empat kabupaten dianalisis berdasarkan anggota yang membentuk aliran distribusi dan peran dari setiap anggota. Anggota rantai pasok adalah para pelaku yang terlibat dalam aliran produk, uang dan informasi yang dimulai dari peternak hingga konsumen akhir. Dalam rantai pasok ayam broiler terdapat rantai ayam hidup dan rantai daging ayam. Peran kunci rantai ayam hidup bermain ditransmisi penyakit flu burung dan kebutuhan untuk menerapkan berbagai langkah-langkah pengendalian untuk mengurangi kematian ayam broiler (Sharon et al. 2014). Fokus penelitian ini pada rantai pasok ayam broiler dalam bentuk ayam hidup dalam konteks pengendalian penyakit.

Rantai pasok ayam broiler memiliki persamaan dan perbedaan. Persamaannya terdapat pada rantai pasok peternak maklun di Kab. Tasikmalaya dan Ciamis. Selain itu, persamaan rantai pasok terjadi pada peternak mandiri di Kab. Tasikmalaya dengan Sukabumi. Persamaan rantai pasok juga terjadi pada peternak PT di Kabupaten Sukabumi dengan di Subang yang melibatkan pihak industri makanan dalam aliran distribusi. Perbedaanya terjadi pada peternak kemitraan di Kabupaten Sukabumi dengan di Subang yang tidak melibatkan industri makanan. Perbedaan lain terdapat pada peternak mandiri di Kabupaten Subang yang berbeda dengan peternak mandiri di Kabupaten lainnya. Perbedaan juga terjadi pada peternak maklun di Kabupaten Ciamis yang melibatkan tiga broker, sedangkan peternak maklun di Kabupaten Tasikmalaya yang hanya melibatkan dua broker. Bagan rantai pasok dapat dilihat pada Gambar 1.

\section{Analisis Perilaku Peternak dalam Pengendalian Penyakit}

Ketika ayam terserang penyakit, peternak harus mengambil tindakan paling tepat dan mampu meminimalkan kerugian. Menurut FAO (2011), mekanisme penyebaran virus HPAI H5N1 terdiri dari enam faktor yaitu berasal dari burung yang terinfeksi, daging dan produk lain yang bearsal dari unggas yang terinfeksi, orang-orang yang kontak langsung dengan unggas terinfeksi, kendaraan yang digunakan, peralatan yang terkontaminasi, dan by product (melalui kotoran unggas, bulu, limbah pemotongan, limbah dari tempat penetasan, dan kulit telur). Peternak Sukabumi, Subang, Tasikmalaya dan Ciamis melakukan tindakan berbeda-beda dalam merespon risiko penyakit ayam pedaging, yaitu dari memisahkan ayam sakit dengan ayam sehat, mengobati ayam, memusnahkan ayam sakit dan menjual semua ayam saat terjadi wabah penyakit. Respon peternak dalam menghadapi risiko penyakit ayam pedaging di empat kabupaten di Jawa Barat dapat dilihat pada Tabel 1.

Tindakan yang banyak dilakukan peternak di Jawa Barat ketika terlihat tanda-tanda ayam terserang penyakit adalah memisahkan ayam terinfeksi dengan ayam yang sehat untuk mencegah penyebaran penyakit ke semua ayam. Sebagian peternak juga melakukan tindakan mengobati ayam hingga sembuh, namun langkah mengobati mengakibatkan penambahan biaya produksi. Dalam hal ini, peternak harus mempertimbangkan umur ayam saat terserang penyakit. Apabila ayam sudah cukup umur dan bobotnya, peternak memilih menjual semua ayam, baik yang sehat maupun sakit untuk meminimalisir kerugian. Langkah terakhir yang dilakukan adalah memusnahkan ayam yang sakit. Namun memusnahkan ayam yang sakit menimbulkan kerugian biaya yang besar, sehingga hanya beberapa peternak yang mau memusnahkan dan dilakukan atas kesadaran sendiri.

Tabel 1. Respon peternak dalam menghadapi wabah penyakit di Jawa Barat

\begin{tabular}{lcccc}
\hline Lokasi & $\begin{array}{c}\text { Memisahkan } \\
\text { ayam (\%) }\end{array}$ & $\begin{array}{c}\text { Mengobati ayam } \\
(\%)\end{array}$ & $\begin{array}{c}\text { Menjual semua } \\
\text { ayam (\%) }\end{array}$ & $\begin{array}{c}\text { Memusnahkan } \\
\text { ayam sakit (\%) }\end{array}$ \\
\hline Ciamis & 57,4 & 19,8 & 19,8 & 3 \\
Tasikmalaya & 51,4 & 13,3 & 34,3 & 1 \\
Sukabumi & 83,7 & 9,2 & 3,1 & 4,1 \\
Subang & 63,7 & 35,3 & 1 & 0 \\
\hline \multicolumn{1}{c}{ Rataan } & 64,1 & 19,4 & 14,5 & 2 \\
\hline
\end{tabular}




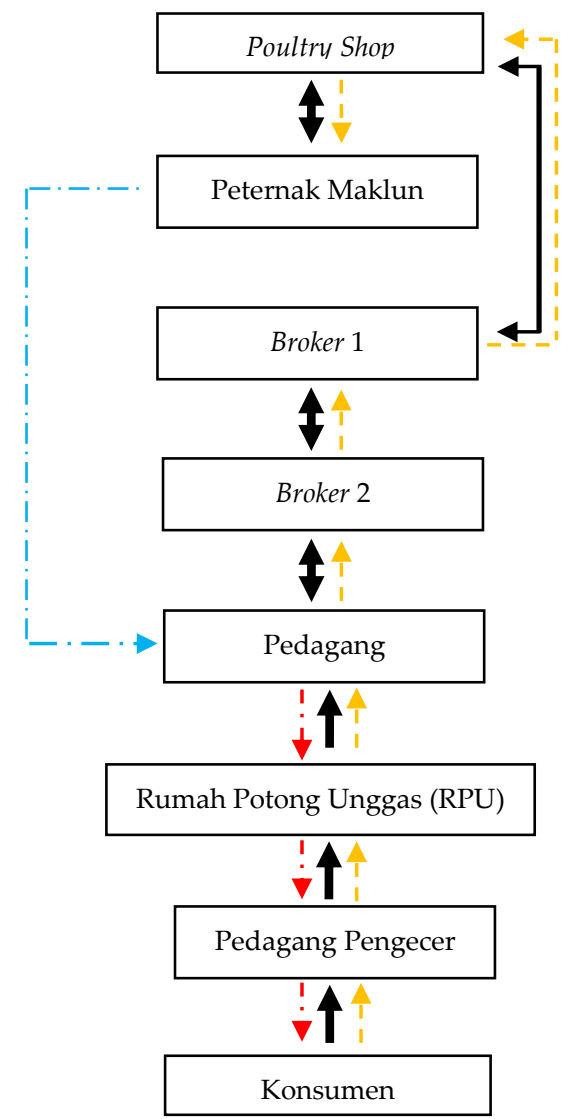

Keterangan:

$\rightarrow$ : Aliran Produk (Ayam Hidup)

$--\rightarrow$ : Aliran Uang

$\rightarrow$ : Aliran Produk (Ayam Karkas)

$\longrightarrow$ : Aliran Informasi

a. Rantai pasok ayam broiler di Kabupaten Ciamis

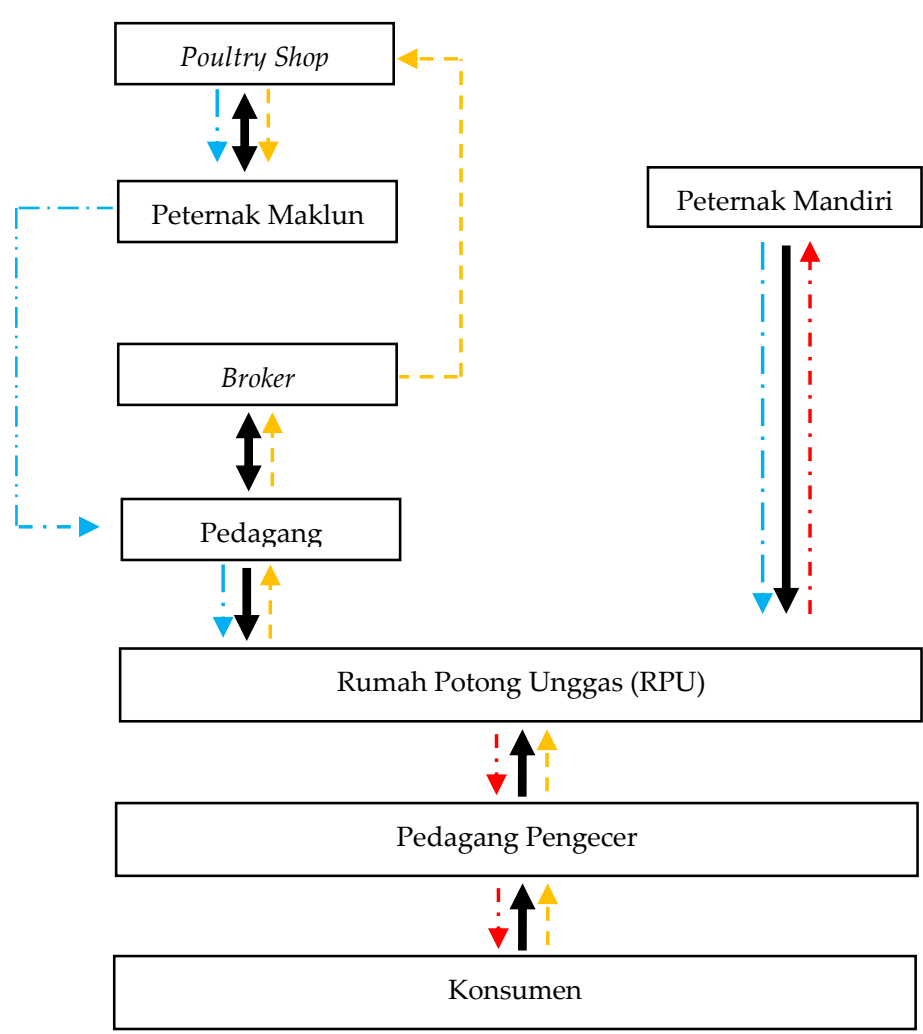

Keterangan:

$-\cdot \rightarrow$ : Aliran Produk (Ayam Hidup)

$--\rightarrow$ : Aliran Uang

: Aliran Produk (Ayam Karkas)

$\longrightarrow$ : Aliran Informasi

b. Rantai pasok ayam broiler di Kabupaten Tasikmalaya

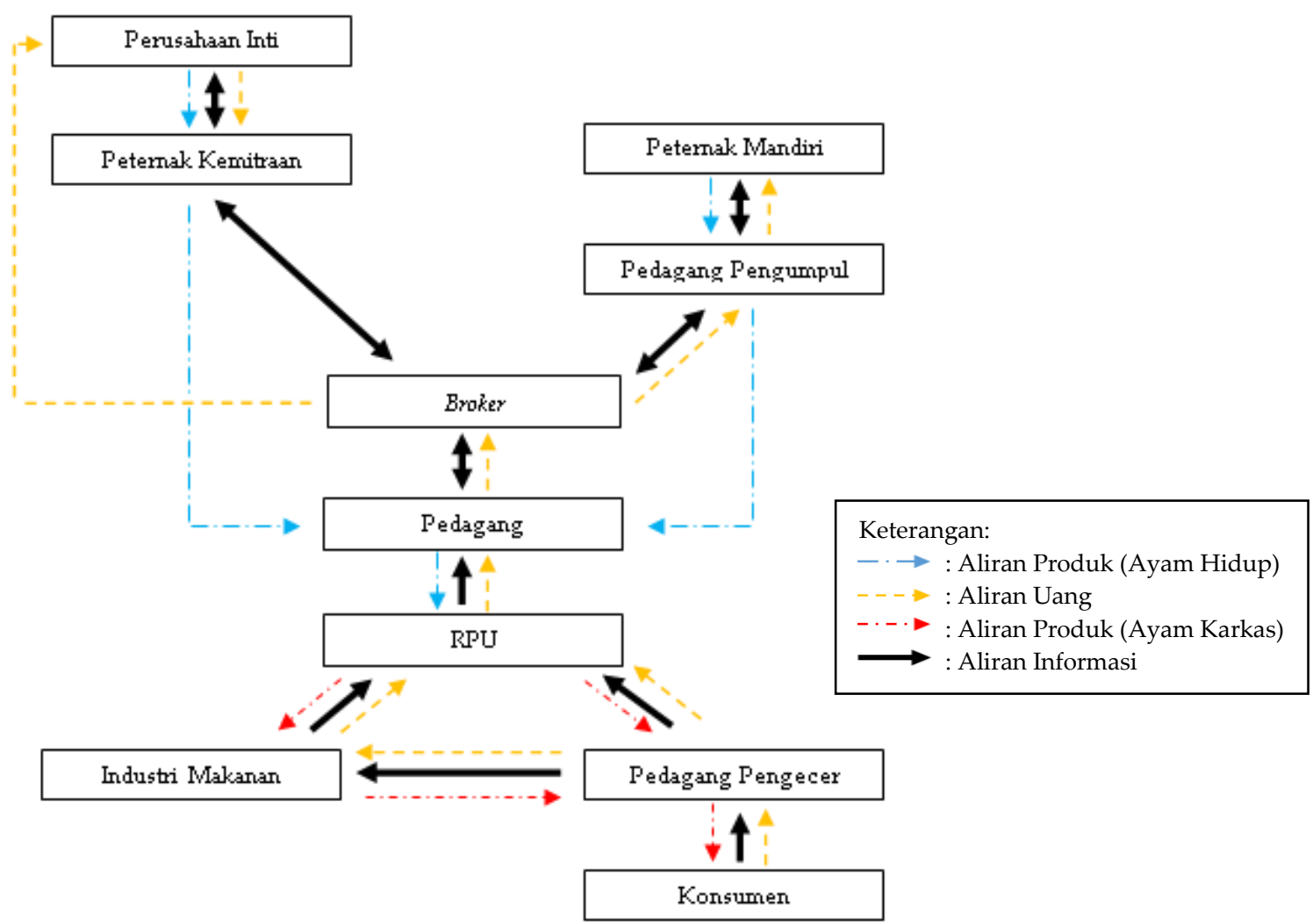

c. Rantai pasok ayam broiler di Kabupaten Subang 


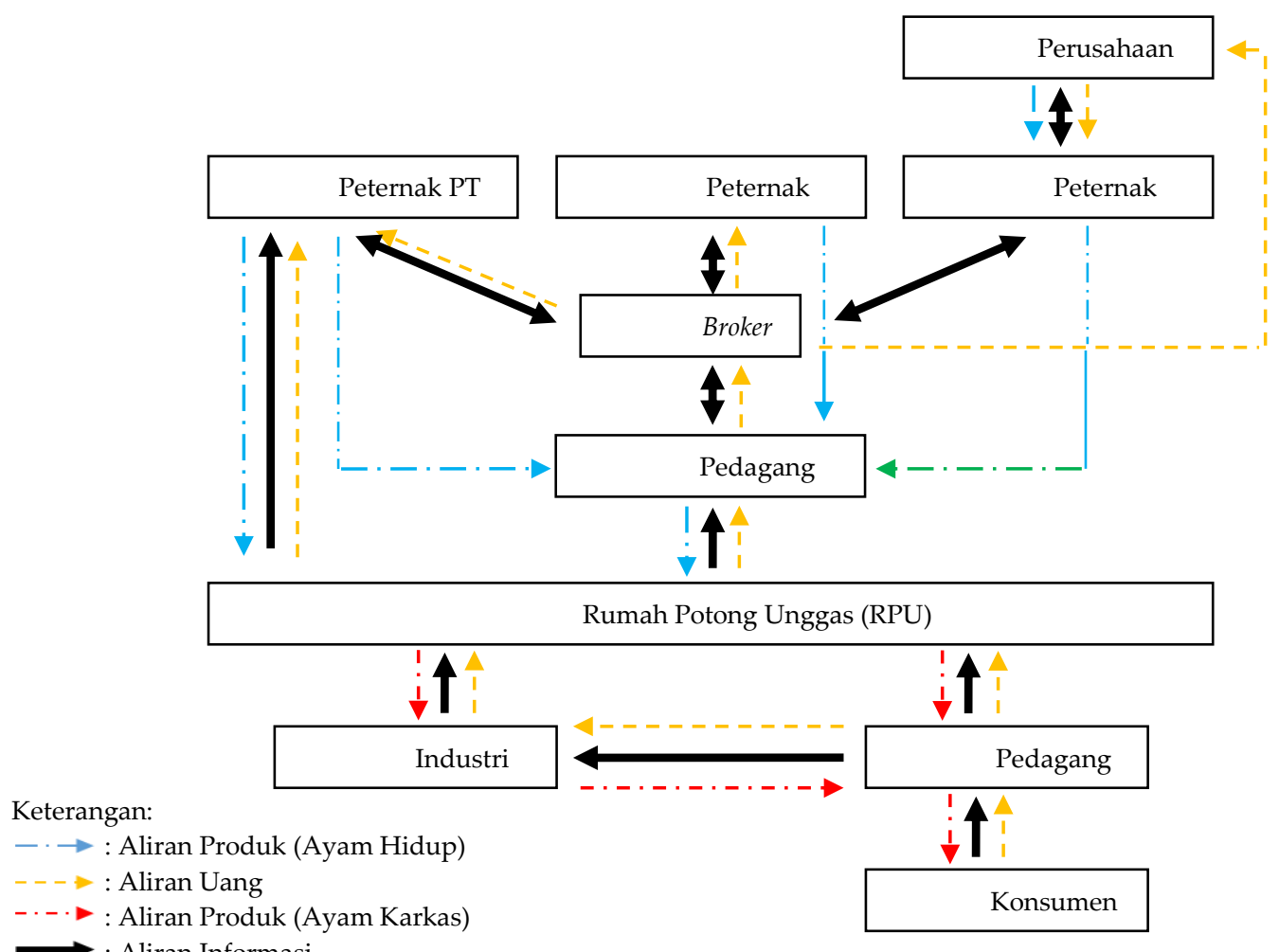

d. Rantai pasok ayam broiler di Kabupaten Sukabumi

Gambar 1. Rantai pasokan ayam broiler di Jawa Barat

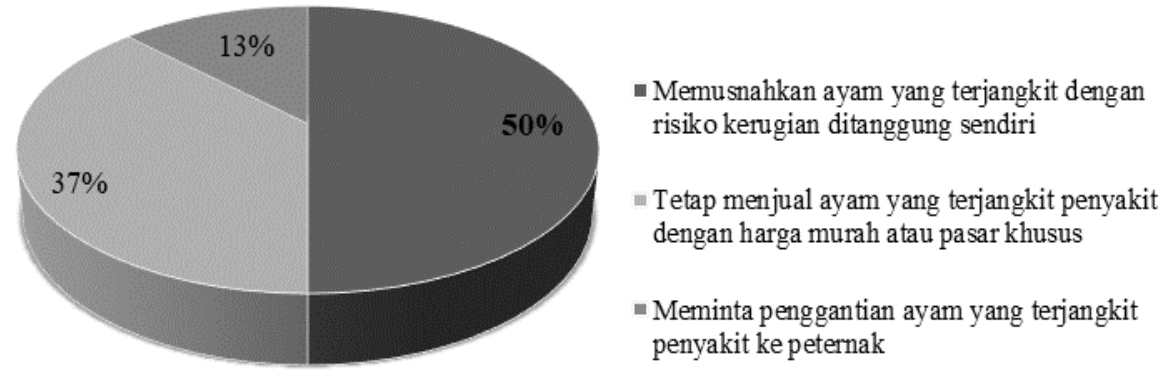

Gambar 2. Perilaku pedagang terhadap ayam broiler yang terjangkit flu burung

\section{Analisis Perilaku Pedagang dalam Pengendalian Penyakit}

Analisis tingkat pengetahuan dan persepsi pedagang terhadap gejala kematian ayam broiler dilakukan untuk pengamatan perilaku pedagang. Perilaku yang diamati adalah pedagang melakukan pengamatan gejala-gejala flu burung pada ayam broiler yang diperdagangkan. Hasil penelitian menunjukkan 53\% pedagang melakukan pengamatan terhadap ayam yang diperdagangkan dan sisanya $(47 \%)$ tidak melakukan pengamatan. Menurut Nofitri (2014), Prioritas faktor rantai pasok terkait AI adalah pada proses produksi ayam dan prioritas anggota rantai pasok adalah pada perusahaan inti, dengan risiko operasional yang memiliki prioritas terbesar adalah sumber daya manusia (SDM).
Melalui data yang diperoleh, dilakukan penelitian terhadap pedagang yang melakukan pengamatan terhadap ayam broiler. Penelitian dilakukan dengan mencari tahu perilaku pedagang pada saat menemukan ayam yang diperdagangkan terdapat gejala-gejala terjangkit flu burung. sesuai hasil penelitian. Hal ini dilakukan untuk mengetahui bagaimana pedagang memitigasi risiko penyebaran penyakit flu burung. Berdasarkan penelitian diperoleh hasil 50\% pedagang akan memusnahkan ayam yang terjangkit dengan risikio kerugian ditanggung sendiri, 37 persen pedagang akan tetap menjual ayam terjangkit penyakit dengan harga lebih murah daripada harga pasar untuk meminimalir kerugian dan 13 persen pedagang berusaha meminta penggantian ayam yang terjangkit penyakit pada peternak (Gambar 2). 


\section{Pengetahuan Pedagang Terhadap Gejala Flu Burung}

Hasil penelitian menunjukkan $68 \%$ pedagang memiliki pengetahuan akan penyakit flu burung. Berdasarkan perolehan persentase tersebut diperoleh perbedaan rataan jumlah gejala yang diketahui pedagang pada setiap kabupaten. Dengan asumsi semakin banyak pengetahuan akan gejala-gejala flu burung, maka akan mengurangi tingkat risiko kematian. Diperoleh hasil penelitian yang menunjukkan pengetahuan pedagang akan gejala-gejala flu burung cukup minim. Rataan pedagang hanya mengetahui tiga dari sembilan gejala ayam yang terjangkit flu burung.

Berdasarkan gejala-gejala flu burung yang disajikan kepada responden diperoleh persentase tingkat pengetahuan pedagang. Persentase paling besar adalah pedagang mengetahui gejala ayam yang terjangkit flu burung dengan terjadinya kematian mendadak pada ayam 33\%. Untuk gejala yang ditandai dengan penampakan ayam yang depresi $15 \%$ dari terjadinya gejala pembengkakan pada kepala, kelopak mata, sisir, pial, dan mulut $11 \%$. Berikut adalah persentase hasil pengetahuan pedagang terhadap gejala ayam yang terjangkit flu burung dimuat dalam Gambar 3.

\section{Analisis Faktor-Faktor yang Memengaruhi Tingkat Kematian Ayam Broiler}

Menurut Sudarman et al. (2010), setiap aktor dalam rantai nilai unggas yang menangani unggas hidup atau baru mati harus mampu mengenali HPAI jika terjadi kasus dan tanggap serta mampu mengambil tindakan yang tepat waktu untuk melaporkan penyakit kejadian tersebut kepada pihak yang berwenang. Suartha et al. (2010) melaporkan bahwa pedagang unggas berkontribusi tinggi dalam penyebaran flu burung karena belum melakukan program biosekuriti secara menyeluruh ditinjau dari pengumpulan unggas sebelum dijual, pencampuran jenis unggas, pencucian keranjang unggas dan desinfeksi keranjang unggas. Analisis regresi linear berganda digunakan untuk menekan dan menurunkan tingkat kematian ayam broiler (Manurung, 2013). Sebelum melakukan regresi linear berganda, penelitian ini terlebih dahulu melakukan uji asumsi klasik. Model analisis regresi linear berganda dikatakan model yang baik, jika terbebas dari asumsi klasik, yaitu terbebas dari uji normalitas, multikolinearitas dan heteroskedastisitas. Hasil analisis menunjukkan model regresi memenuhi asumsi normalitas, karena titik-titik pada grafik uji normalitas mengikuti dan mendekati garis diagonalnya. Hasil

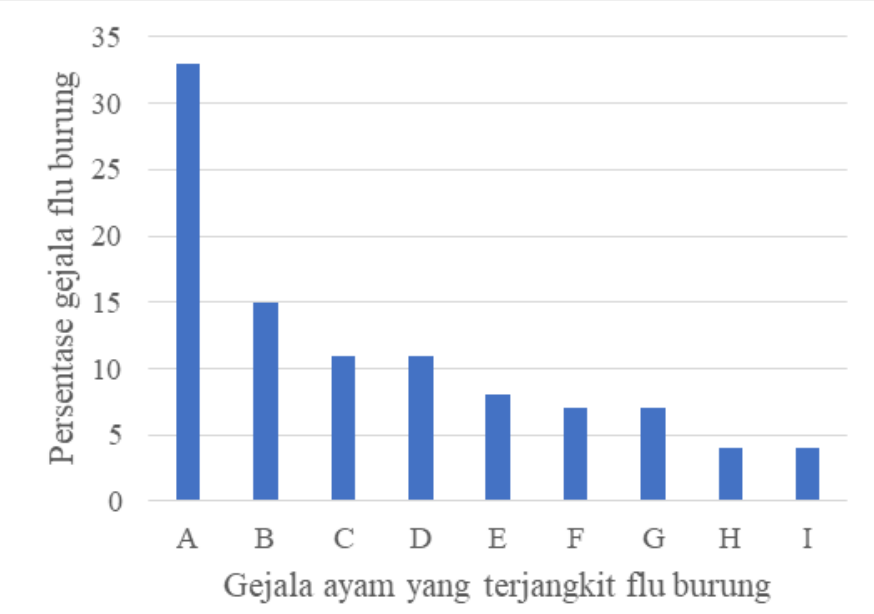

Keterangan:

A : Peningkatan kematian secara mendadak

F : Diare

B : Depresi

G : Pendarahan pin point

C : Pembengkakan kepala, kelopak mata,

$\mathrm{H}$ : Keluarnya darah-kebiruan dari lubang hidung sisir, pial dan mulut

D : Gangguan Pernapasan

I : Inkoordinasi termasuk hilangnya kemampuan berjalan dan berdiri

E : Bulu rontok

Gambar 3. Persentase gejala-gejala ayam terkena flu burung yang diketahui pedagang 
uji kedua, yaitu uji multikolinearitas menunjukkan bahwa semua peubah independen memiliki nilai variance inflation factor (VIF) $<10$. Hasil tersebut menunjukkan model regresi tidak mengandung multikolinearitas. Hasil uji heteroskedastisitas menunjukkan titik-titik pada grafik tidak membentuk pola yang jelas (menyebar) di atas dan di bawah angka 0 pada sumbu $Y$, sehingga menunjukkan tidak terjadi masalah heteroskedastisitas pada model regresi. Dari keseluruhan uji asumsi klasik dapat disimpulkan bahwa model dapat dikatakan baik karena terbebas dari asumsi klasik.

Selanjutnya menganalisis faktor-faktor yang memengaruhi tingkat kematian ayam broiler. Analisis ini bertujuan menganalisis faktor-faktor yang memengaruhi tingkat kematian ayam broiler dengan analisis regresi linear berganda. Peubah terikat (Y) digunakan adalah nilai jumlah kematian ayam broiler per ekor dan peubah bebas (X) meliputi jarak, jumlah pembelian ayam per bulan, pengetahuan pedagang pada gejala flu burung, log natural dari biaya disinfektan per ekor dan moda transportasi.

Peubah jarak digunakan karena menunjukkan seberapa lama jarak tempuh pengiriman ayam untuk mencegah kematian ayam broiler saat dalam perjalanan. Peubah jumlah pembelian ayam per bulan digunakan untuk menunjukan kapasitas pembelian per bulan yang dilakukan pedagang untuk mencegah kepadatan ayam broiler dalam keranjang. Selain itu, peubah pengetahuan pedagang pada gejala flu burung digunakan untuk menunjukan pengetahuan pengetahuan pedagang mengenai gejala flu burung untuk mengurangi kematian ayam. Peubah log natural dari biaya disinfektan per ekor digunakan untuk menunjukan perlakuan pedagang terhadap kendaraan dan keranjang selama dalam penampungan untuk mencegah kontaminasi. Kemudian peubah moda transportasi digunakan untuk menunjukan perlakuan pedagang terhadap kendaraan selama distribusi untuk mencegah kepadatan ayam broiler. Kontribusi peubah bebas terhadap peubah terikat pada penelitian ini disajikan pada Tabel 2 .

Tabel 2 menunjukkan hasil $R$ square 0.649 atau $64,9 \%$, yaitu hasil kuadrat dari koefisien korelasi. Hasil tersebut menunjukkan kontribusi semua peubah bebas terhadap jumlah kematian ayam broiler per ekor $64.9 \%$, sedangkan sisanya dijelaskan oleh peubah lain di luar penelitian.

Tabel 2. Kontribusi peubah bebas terhadap peubah terikat

\begin{tabular}{cccc}
\hline Model & $\mathrm{R}$ & $R$ Square & Adjusted $R$ Square \\
\hline 1 & $0.850^{\mathrm{a}}$ & 0.649 & 0.539 \\
\hline
\end{tabular}

Berdasarkan Tabel 3, hasil uji pengaruh secara parsial diperoleh bahwa jarak berpengaruh nyata dan positif terhadap jumlah kematian ayam broiler per ekor. Hal ini karena nilai sig. 0.001 lebih kecil dari alpha $10 \%$. Selain itu, jumlah pembelian ayam per bulan berpengaruh nyata dan positif terhadap jumlah kematian ayam broiler per ekor. Hal ini karena nilai sig. Sebesar 0.017 lebih kecil dari alpha $10 \%$. Pengetahuan pedagang pada gejala flu burung berhubungan negatif nyata terhadap tingkat kematian ayam broiler.

\section{Uji Pengaruh Peubah Bebas Terhadap Peubah Terikat}

Uji pengaruh peubah bebas terhadap peubah terikat secara parsial bertujuan menguji keberhasilan koefisien regresi secara parsial. Pengujian ini dilakukan untuk menganalisis peubah bebas $(X)$ secara tunggal berpengaruh terhadap peubah terikat $(\mathrm{Y})$ dengan membandingkan nilai $\mathrm{t}$ hitung masing-masing peubah bebas dengan derajat kesalahan 10\% $(\alpha=0.10)$. Hasil uji t secara ringkas disajikan pada Tabel 3.

Tabel 3. Hasil uji pengaruh peubah bebas terhadap peubah terikat secara parsial

\begin{tabular}{lccc}
\hline \multicolumn{1}{c}{ Model } & B & Sig. & Keterangan \\
\hline (Constant) & $\mathbf{1 6 4 1 . 1 0 0}$ & $\mathbf{0 . 9 4 1}$ & \\
Jarak $\left(\mathrm{X}_{1}\right)$ & $\mathbf{1 5 5 2 . 4 6 6}$ & $\mathbf{0 . 0 0 1}$ & Nyata \\
Jumlah pembelian ayam per bulan $\left(\mathrm{X}_{2}\right)$ & $\mathbf{0 . 7 8 1}$ & $\mathbf{0 . 0 1 7}$ & Nyata \\
Pengetahuan pedagang pada gejala flu burung $\left(\mathrm{X}_{3}\right)$ & $\mathbf{- 2 3 7 9 6 . 6 3 2}$ & $\mathbf{0 . 0 5 2}$ & Nyata \\
Log natural dari biaya disinfektan per ekor $\left(\mathrm{X}_{4}\right)$ & -2313.573 & 0.491 & Tidak nyata \\
Moda transportasi $\left(\mathrm{X}_{5}\right)$ & 2744.967 & 0.790 & Tidak nyata \\
\hline
\end{tabular}


Peubah log natural dari biaya disinfektan per ekor dan moda transportasi terbukti tidak berpengaruh nyata terhadap tingkat kematian ayam broiler. Hal tersebut karena nilai sig. kedua peubah lebih besar dari alpha 10\%. Dari hasil tersebut dapat dirumuskan persamaan regresi linear berganda, yang disajikan pada Persamaan 1 .

$$
\begin{gathered}
Y=1641.100+1552.466 X_{1}+0.781 X_{2}-23796.632 X_{3}- \\
2313.753 X_{4}+2744.967 X_{5}
\end{gathered}
$$

Keterangan:

$\mathrm{Y}=$ Tingkat kematian ayam broiler (ekor)

$\mathrm{X}_{1}=$ jarak (kilometer)

$\mathrm{X}_{2}=$ Jumlah pembelian ayam per bulan (ekor)

$\mathrm{X}_{3}=$ Pengetahuan pedagang pada gejala flu burung (persen)

$\mathrm{X}_{4}=$ Log natural dari biaya disinfektan per ekor

$\mathrm{X}_{5}=$ Moda transportasi

Berdasarkan persamaan regresi linear berganda yang diperoleh dapat dijelaskan bahwa jumlah kematian ayam broiler per ekor akan bertambah setiap terjadinya pertambahan jarak dalam pendistribusian ayam broiler. Apabila semakin jauh jarak yang ditempuh selama transportasi, maka dapat menyebabkan ayam stress, kepanasan apabila pengiriman dialakukan pada saat cuaca panas dan kedinginan, apabila pengiriman dilakukan pada saat cuaca dingin.

Jumlah kematian ayam broiler per ekor akan bertambah setiap terjadinya pertambahan jumlah pembelian ayam per bulan, maka semakin banyak jumlah pembelian ayam broiler per bulan, dapat menyebabkan kepadatan ayam broiler didalam keranjang maupun kendaraan yang digunakan saat transportasi.

Jumlah kematian ayam broiler per ekor akan bertambah bila terjadi kekurangan persepsi pada pengetahuan pedagang pada gejala flu burung. Artinya bila pedagang tidak memiliki pengetahuan mengenai gejala flu burung, maka akan mengalami kematian ayam lebih banyak selama satu kali pembelian. Untuk itu, pedagang dituntut mengetahui gejala-gejala ayam yang terkena flu burung dan tindakan antisipasi terhadap hal tersebut.

\section{Implikasi Manajerial}

Implikasi manajerial yang dapat menjadi rekomendasi bagi stake holder berdasarkan hasil penelitian adalah sebagai dasar dalam membuat kebijakan terkait pengambilan keputusan dan strategi pengelolaan ayam broiler. Pengambilan keputusan terbentuk dengan memperhatikan aspek pengetahuan akan gejala penyakit ayam, banyaknya pelaku dalam aliran rantai pasok dan panjangnya rantai pasokan.

Pengetahuan akan gejala penyakit ayam broiler perlu diperhatikan dan ditingkatkan sehingga pelaku usaha mampu mencegah dan meminimalisir tingkat kematian. Pengetahuan akan mempengaruhi perilaku pelaku usaha dalam mencegah risiko penyakit. Pemeliharaan kendaraan dan keranjang menjadi salah satu usaha dalam pencegahan kematian akibat risiko penyakit. Pelaku usaha perlu melakukan pembersihan dan penyemprotan disinfektan sebelum dan setelah pengangkutan secara berkala. Aspek waktu, jarak dan moda transportasi pengiriman juga perlu diperhatikan. Semakin banyak pelaku usaha dalam rantai pasokan maka akan semakin panjang rantai. Panjangnya suatu rantai pasokan berkaitan dengan aspek waktu, jarak, dan moda transportasi yang digunakan. Berdasarkan aspek-aspek tersebut stake holder perlu memperhatikan alternatif pengambilan keputusan sehingga diperoleh hasil yang optimal dengan tingkat kematian ayam seminimal mungkin.

\section{KESIMPULAN}

1. Peternak dan pedagang sangat berperan penting dalam pengendalian penyakit unggas, dikarenakan potensi penyebaran penyakit pada rantai pasok ayam hidup dimulai pada saat ayam broiler di kandang hingga sampai ke Rumah Potong Unggas (RPU). Pelaku yang berperan dalam rantai pasok ayam hidup meliputi peternak, Broker, Pedagang, dan RPU. Pada umumnya panjang rantai dipengaruhi banyaknya broker yang berperan. Semakin panjang rantai pasok ayam hidup, maka akan berpengaruh pada harga pembelian ayam atau insentif yang diperoleh rendah, sehingga para pelaku usaha tidak mampu mengeluarkan biaya disinfektan.

2. Mayoritas pedagang dan peternak memiliki pengetahuan akan gejala flu burung. sehingga menurunkan risiko kematian ayam broiler. Sebagai contoh $64 \%$ peternak memilih memisahkan ayam sakit dengan ayam sehat, 22\% memilih mengobati ayam sakit, 11\% menjual semua ayam sakit dan 3\% memusnahkan ayam sakit. Ditingkat pedagang separuhnya berinisiatif melakukan pemusnahan terhadap ayam 
dengan menanggung risiko kerugian dan separuh lainnya tetap menjual.

3. Pedagang beranggapan bahwa tidak ada pengaruh nyata penyebaran penyakit terhadap tingkat kematian ayam pada saat pendistribusian ayam. Jumlah kematian ayam terbukti nyata meningkat seiring peningkatan skala pembelian dan jarak tempuh.

\section{DAFTAR PUSTAKA}

A. McLeod et al. 2009. Poultry value chain mapping: World's Poultry Science Journal, Vol. 65, June 2009

[BPS] Badan Pusat Statistik Povinsi Jawa Barat. 2015. Jawa Barat dalam Angka 2015. Bandung (ID): Badan Pusat Statistik Provinsi Jawa Barat.

Cardona, C., K. Yee, Carpenter. 2009. Are Live Bird Marker Reservoirs of Avian Influenza. Poultry Science. 88: hlm 856-859

[Disnak] Dinas Peternakan Jawa Barat. 2016. Laporan Tahunan Dinas Peternakan Provinsi Jawa Barat. [internet]. [diunduh 2016 Februari 05]. Tersedia pada http://disnak. jabarprov. go.id/.

[Ditjennak] Direktorat Jendral Peternakan dan Kesehatan Hewan. 2016. Statistik Peternakan dan Kesehatan Hewan [Internet]. [diunduh 2016 april 30]. Tersedia pada: http://ditjennak. pertanian.go.id.
Food and Agriculture Organizations of The United Nation (FAO). 2011. A Value Chain Approach To Animal Diseases Risk Management-Technical Foundations and Practical Frame-work for Field Application. Animal Productions and Health Guidelines. No.4. Rome.

Manurung, N. 2013. Analisis Faktor Angka Kematian Bayi terhadap Penolong Kelahiran di Sumatera Utara. Medan (ID): Univesitas Sumatera Utara.

Mulyantini, N.G.A. 2010. Ilmu Manajemen Ternak Unggas. Yogyakarta (ID): Penerbit Gadjah Mada University Press.

Nofitri, Z. 2014. Manajemen Risiko Rantai Pasok Unggas Terkait Kasus Avian Influenza di Kabupaten Bandung. Bogor (ID): Institut Pertanian Bogor.

Suartha, I.N., I.M.S. Antara, I.K.S. Wiryana, Sukada IM, Wirata IW, Dewi NMRK, Mahardika IGNK. 2010. Peranan pedagang unggas dalam penyebaran virus Avian Influenza. J Vet 11(4): 220-225.

Sudarman, A., K.M. Rich, T. Randolph, F. Unger. 2010. Poultry value chains and HPAI in Indonesia: The case of Bogor.

Yupiana, Y., S.J. de Vlas, N.M. Adnan, J.H. Richardus. 2010. Risk factors of poultry outbreaks and human cases of H5N1 avian influenza virus infection in West Java Province, Indonesia. International Journal of Infectious Diseases. 14: e800-e805. Doi:10.1016/j.ijid.2010.03.014 